\title{
Acaricide resistance of Rhipicephalus (Boophilus) microplus in State of Mato Grosso do Sul, Brazil
}

\author{
Resistência do Rhipicephalus (Boophilus) microplus aos acaricidas no Estado de Mato Grosso do Sul, Brasil \\ Renato Andreotti ${ }^{1 *}$; Felix David Guerrero ${ }^{2}$; Mariana Aparecida Soares ${ }^{1}$; Jacqueline Cavalcante Barros ${ }^{1}$; \\ Robert John Miller; Adalberto Pérez de Léon ${ }^{2}$
}

${ }^{1}$ Embrapa Beef Cattle

${ }^{2}$ USDA-ARS Knipling-Bushland US Livestock Insects Research Laboratory

${ }^{3}$ USDA-ARS Cattle Fever Tick Research Laboratory

Received October 25, 2010

Accepted February 17, 2011

\begin{abstract}
This study was conducted to obtain an epidemiological view of acaricide resistance in populations of Rhipicephalus (Boophilus) microplus in the State of Mato Grosso do Sul. Twenty-four tick samples were collected from municipalities in the State where farmers had reported concerns about resistance to or failure of tick control. These ticks were subjected to in vitro resistance detection assays using the adult immersion test (AIT). The efficacy of alpha-cypermethrin, cypermethrin and amitraz treatments on samples collected throughout the State was generally poor. AIT showed efficacy $\geq 90 \%$ from the use of DDVP + chlorfenvinphos) (20 out of 21 municipalities), dichlorvos + cypermethrin (10 out of 16 municipalities) and cypermethrin + citronella + chlorpyrifos + piperonyl butoxide (20 out of 21 municipalities). PCR assays were used to detect the presence of pyrethroid resistance-associated sodium channel gene mutation. Larvae from three different populations that had previously been diagnosed as pyrethroid-resistant, through AIT, were evaluated. The PCR assays showed that the pyrethroid resistance-associated gene mutation was absent from these three populations. This study confirms that the emergence of resistance is a constant challenge for the livestock industry, and that development of resistance continues to be a major driver for new antiparasitic drugs to be developed.
\end{abstract}

Keywords: Tick, control, bovine, acaricide, PCR.

\section{Resumo}

Este estudo foi realizado com o objetivo de se obter uma visão epidemiológica da resistência aos acaricidas nas populaçóes de Rhipicephalus (Boophilus) microplus no Estado de Mato Grosso do Sul. Vinte e quatro amostras de carrapatos foram coletadas em cidades do estado onde os fazendeiros relataram preocupaçáo com resistência ou falha no controle dos carrapatos. Estes carrapatos foram submetidos a testes de detecção de resistência in vitro usando o teste de imersão de adultos (TIA). A eficácia do tratamento com alfa-cipermetrina, cipermetrina e amitraz foi geralmente pobre nas amostras coletadas em todo o Estado. Obteve-se eficácia de $\geq 90 \%$ no TIA com o DDVP + chlorfenvinphos (20 das 21 cidades), Diclorvós + Cipermetrina (10 das 16 cidades), e Cipermetrina + Citronela + Clorpirifós + Butóxido de piperonila (20 das 21 cidades). O ensaio da PCR foi utilizado para detectar a presença de mutação do gene do canal de sódio associado à resistência a piretróide. Avaliaram-se larvas de três diferentes populaçóes onde anteriormente foi diagnosticada à resistência por TIA. Os ensaios da PCR mostraram que a mutação no gene associado à resistência ao piretróide estava ausente nessas três populaçóes. Esse estudo confirma que o surgimento da resistência é um constante desafio para a pecuária e o desenvolvimento de resistência continua a ser um importante estímulo para o desenvolvimento de novas drogas antiparasitárias.

Palavras-chave: Carrapato, controle, bovinos, acaricida, PCR.

\footnotetext{
${ }^{*}$ Corresponding author: Renato Andreotti 


\section{Introduction}

Over 170 million cattle are managed by the Brazilian livestock industry (ANUALPEC, 2009). However, the industry's productivity is undermined by the tick species Rhipicephalus (Boophilus) microplus (Canestrini, 1887) (Acari: Ixodidae). In addition to the direct effects of $R$. (B.) microplus infestation on milk, meat and leather production, this tick species also serves as a vector for the infectious agents that cause bovine babesiosis and anaplasmosis. The annual economic loss suffered by the Brazilian livestock industry attributable to $R$. (B.) microplus parasitism is estimated to be over US\$ 2 billion (GRISI et al., 2002).

One common practice for controlling $R$. (B.) microplus is to use commercial acaricides and, historically, this proved to be an effective strategy for mitigating the tick's economic impact on the livestock industry. However, the evolution of acaricide resistance in populations of $R$. (B.) microplus is a cause of grave concern among cattle producers, government agencies and technical personnel.

Information concerning the regional distribution of $R$. (B.) microplus and the prevalence of acaricide resistance among Brazilian tick populations is limited. Consequently, selection and use of acaricides is based on criteria other than effectiveness, and applications are often inadequate, which may result in costly and ineffective treatment. Compounding this situation in Brazil, horn flies (Haematobia irritans) can be controlled using products with acaricidal activity (pyrethroids and organophosphates) at dosages that are insufficient to ensure tick control. This indirectly contributes towards increasing the likelihood that resistant tick populations will develop (BARROS et al., 2007).

The earliest records of acaricide resistance in Brazilian populations of $R$. (B.) microplus relate to arsenic use and date from 1953 (FREIRE, 1953). Resistance has been confirmed for organochlorines, organophosphates, synthetic pyrethroids (ARANTES et al., 1995), amidines and macrocyclic lactones (MARTINS; FURLONG, 2001; KLAFKE et al., 2006). There have not yet been any reports on the evolution of fluazuron or spinosad resistance in field populations of $R$. (B.) microplus (ANDREOTTI, 2010).

Between 1975 and 1984, Mexico conducted a national campaign against $R$. (B.) microplus. The campaign failed, and this was largely due to development of resistance to organophosphates. Since then, widespread and increasing resistance to organophosphate and pyrethroid acaricides in Mexico has become a major concern for the United States, since the organophosphate coumaphos is the only approved acaricide for use against cattle fever ticks in the United States (MILLER et al., 2005).

An evaluation on the susceptibility of $R$. (B.) microplus to acaricides in Mato Grosso do Sul within the last decade showed that pyrethroid effectiveness was generally less than 70\%, although mixtures of DDVP-chlorfenvinphos and cypermethrin-chlorpyrifospiperonyl-citronella showed $97.68 \%$ and $100 \%$ effectiveness, respectively (KOLLER et al., 2009). There have not been any reports of mechanistic studies within these pyrethroid-resistant populations. Information on the molecular basis of resistance is important for tick control program managers, because molecular and biochemical diagnostic tests developed from knowledge of the mechanisms of resistance can be used to monitor acaricide susceptibility and to measure the success of interventions involving rotation of acaricides with different modes of action.

A polymerase chain reaction-based assay to detect the presence of pyrethroid resistance-associated sodium channel gene mutation is a useful tool for investigating resistance mechanisms in cattle ticks. This assay detects a nucleotide difference that causes Phe to Ile amino acid substitution in the $\mathrm{S} 6$ transmembrane segment of domain III of the para-like sodium channel, and it clearly distinguishes heterozygotes from homozygotes (GUERRERO et al., 2001). Studies have shown that this mutation correlates with flumethrin, deltamethrin and cypermethrin resistance in Mexican tick populations (JAMROZ et al., 2000; ROSARIO-CRUZ et al., 2005).

The aim of the present study was to obtain an emerging view of the epidemiology of acaricide resistance among populations of $R$. (B.) microplus in the State of Mato Grosso do Sul.

\section{Material and Methods}

\section{Tick samples}

Adult females of $R$. (B.) microplus were collected from cattle in the State of Mato Grosso do Sul, which is located between the latitudes $17^{\circ} 34^{\prime}$ and $23^{\circ} 56^{\prime} \mathrm{S}$, and the longitudes $51^{\circ} 40^{\prime}$ and $57^{\circ} 39^{\prime} \mathrm{W}$. This area is characterized by an annual mean temperature of $26^{\circ} \mathrm{C}$ (range: $17-35^{\circ} \mathrm{C}$ ), annual mean relative humidity of $80 \%$ and annual rainfall of $1,500 \mathrm{~mm}$. Collection of these specimens formed part of a monitoring project in which farmers accessed the internet to send information and ticks to the laboratory at Embrapa Beef Cattle in Campo Grande, Mato Grosso do Sul.

In 2009, R. (B.) microplus ticks were collected from ranches in Mato Grosso do Sul where farmers had expressed concerns about resistance to or failure of tick control management and these ticks were subjected to in vitro resistance detection assays. Twenty-four samples were collected from the following 21 municipalities in Mato Grosso do Sul: Anastácio, Bataguassu, Caarapó, Chapadão do Sul (three farms), Corguinho, Dourados, Iguatemi, Inocência, Itaquiraí, Naviraí, Nova Alvorada do Sul, Paraiso, Paranaíba, Ponta Porã, Ribas do Rio Pardo, Rio Negro, Rochedo, São Gabriel do Oeste, Sidrolândia (two farms), Sonora and Terenos. The location of each municipality within the State is shown in Figure 1.

\section{Adult immersion test (AIT)}

The AIT was used to test fully engorged females, of size greater than $4.5 \mathrm{~mm}$ (DRUMMOND et al., 1973), under standard laboratory conditions of $28{ }^{\circ} \mathrm{C}$ and $80 \%$ relative humidity. Acaricidal products containing alpha-cypermethrin $(0.015 \%)$, cypermethrin $(0.015 \%)$ and amitraz $(0.025 \%)$ as the single active ingredient were tested separately using the AIT. The following acaricidal products with active ingredient combinations were also tested: dichlorvos $(0.1125 \%)+$ cypermethrin $(0.0125 \%)$; chlorpyrifos $(0.04 \%)+$ cypermethrin $(0.0165)$; DDVP $(0.15 \%)+$ deltamethrin $(0.0025 \%)$; DDVP $(0.15 \%)+$ chlorfenvinphos $(0.05 \%)$; ethion $(0.06 \%)+$ cypermethrin $(0.008 \%)$; cypermethrin $(0.015 \%)+$ citronella $(0.001 \%)+$ chlorpyrifos $(0.025 \%)+$ piperonyl butoxide 


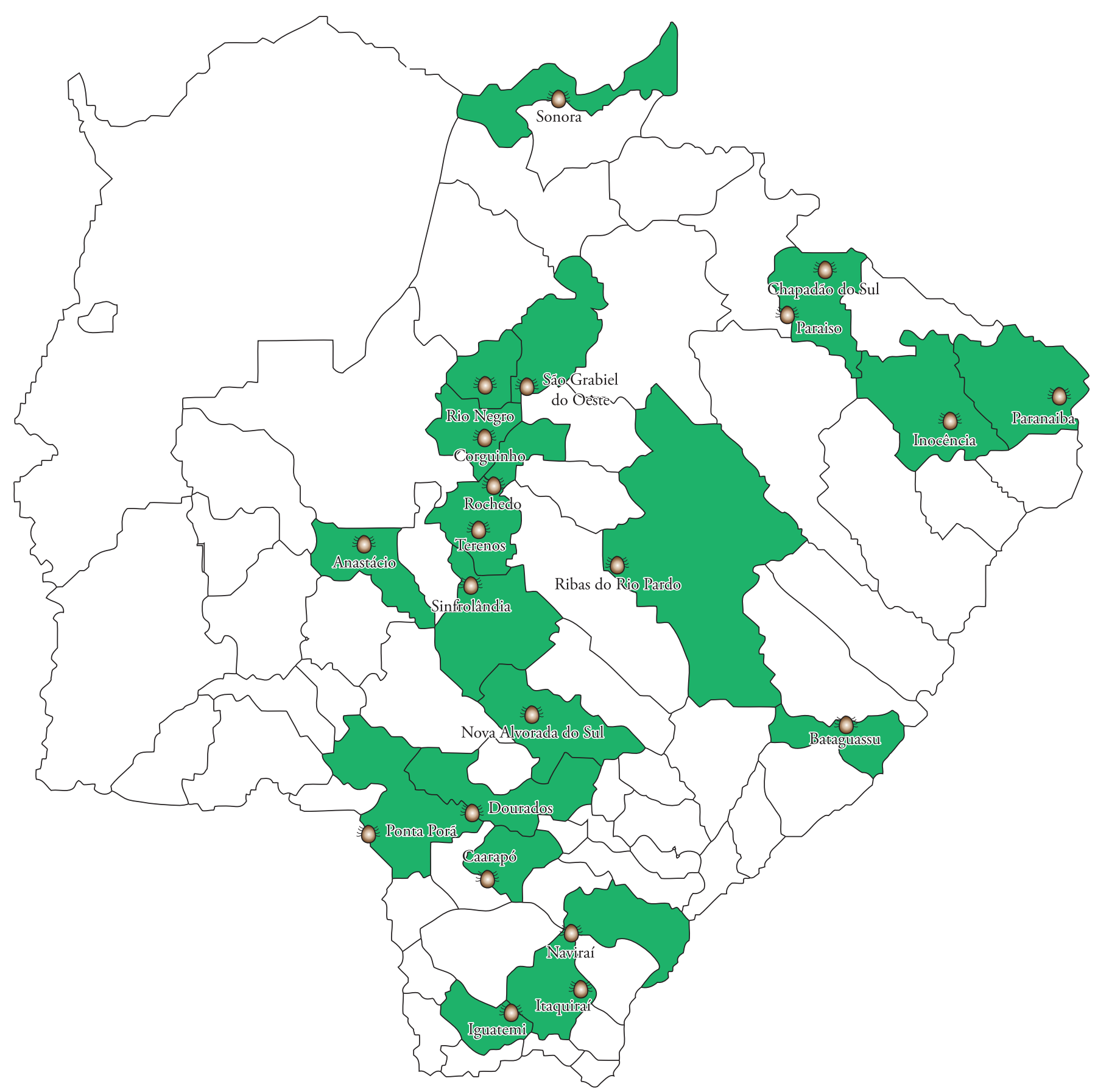

Figure 1. Locations of samples collected in the State of Mato Grosso do Sul.

$(0.015 \%)$; and dichlorvos $(0.15 \%)+$ chlorpyrifos $(0.05 \%)$; DDVP $(0.15 \%)+$ cypermethrin $(0.1125 \%)$.

These products were commercially available and used in accordance with the manufacturer's recommendations and following the commercial dosages of active ingredient used by farmers. Each test was performed in duplicate with 20 females per group, with an average tick weight of $250 \mathrm{mg}$. The ticks were immersed for 5 minutes in the solution containing the acaricide diluted in water, after which they were dried with absorbent paper and transferred to Petri dishes. The ticks were fastened to the dish with sticky tape for monitoring. A control group was subjected to the same conditions, but the ticks were immersed in distilled water. Effectiveness was reported as the effect on the estimated reproduction (ER) of the adult females in a treatment group. ER was calculated as follows: $\mathrm{ER}=\mathrm{g}$ egg $/ \mathrm{g}+\mathrm{P} \times$ estimated $\%$ hatch $\times 20,000$. The control over reproduction that was achieved was calculated as follows: $\sum E R$ untreated $-\sum E R$ treated $/ \sum E R$ untreated $\times 100=\%$ control (DRUMMOND et al., 1973). Treatments were considered effective when the control over reproduction was $\geq 90 \%$. 
A colony of the Mozzo strain that originated from the region of the same name in Uruguay was established in our laboratory and has been maintained under standard laboratory conditions in the absence of acaricide pressure for multiple generations. This strain was used as a pyrethroid-sensitive reference strain.

\section{DNA purification}

A subset of females was allowed to oviposit, and the resulting larvae were used to purify genomic DNA. The larvae were frozen in plastic vials placed in dry ice or liquid nitrogen and were kept frozen, in storage, until the time of analysis. Individual larvae were then transferred onto a petri plate on dry ice and placed in individual $1.5 \mathrm{~mL}$ microcentrifuge tubes, which were also kept on dry ice.

Twenty microliters of sample buffer (100 mM Tris, $\mathrm{pH} 8.3$; $500 \mathrm{mM} \mathrm{KCl}$ ) was added to each tube. A disposable pellet pestle for $1.5 \mathrm{~mL}$ centrifuge tubes (Kontes, Vineland, NJ) was used to crush and grind the larva against the tube wall for 20 seconds, until close visual inspection ensured that the larva was broken into several fragments. The tube was transferred back to dry ice until a set of larvae had been prepared. The tubes were briefly microcentrifuged to ensure that their content of liquid and crushed larva were at the bottom of the tube, and then the tubes were placed in a boiling water bath for 3 minutes. After cooling, $1 \mu \mathrm{L}$ was used for PCR as described by Guerrero et al. (2001).

Larval genomic DNA isolation and genotyping by means of PASA was performed as described by Guerrero et al. (2001) in thin-walled $0.5 \mathrm{~mL}$ microcentrifuge tubes using $20 \mu \mathrm{L}$ reactions optimized for primer annealing temperature and $\mathrm{MgCl}_{2}$ concentration. The final optimized reaction conditions consisted of $1 \mu \mathrm{L}$ of genomic DNA homogenate from a single tick larva, $20 \mathrm{pmol}$ of each primer, $10 \mathrm{mM}$ Tris (hydroxymethyl) aminomethane hydrochloride $\mathrm{pH}=8.3,50 \mathrm{mM} \mathrm{KCl}, 0.05 \mathrm{mM}$ of each dNTP, $1.75 \mathrm{mM} \mathrm{MgCl}_{2}$ and $0.1 \mu \mathrm{L}$ of $1: 1 \mathrm{vol} / \mathrm{vol} \mathrm{mix}$ of AmpliTaq DNA polymerase ( $5 \mathrm{U} \cdot \mu \mathrm{L}^{-1}$ stock) and TaqStart antibody $\left(1.1 \mu \mathrm{g} . \mu \mathrm{L}^{-1}\right.$ stock $)$.

Amplification was carried out using an MJ DNA engine programmed for $96^{\circ} \mathrm{C}$ for 2 minutes followed by 37 cycles, each consisting of denaturation at $94^{\circ} \mathrm{C}$ for 1 minute, annealing at $60{ }^{\circ} \mathrm{C}$ for 1 minute and extension at $72{ }^{\circ} \mathrm{C}$ for 1 minute. The program also included a final extension step at $72{ }^{\circ} \mathrm{C}$ for 7 minutes. The following primers were used: $5^{\prime}$-TTATCTTCGGCTCCTTCT-3' (wild type-specific sense), 5'-TTATCTTCGGCTCCTTCA-3' (mutant-specific sense) and 5'-TTGTTCATTGAAATTGTCGA-3' (non-specific antisense). At least twenty individual larvae from each tick family were tested to determine $\mathrm{kDr}$-genotype frequencies. Electrophoresis was carried out on $2.5 \%$ agarose gels, followed by ethidium bromide staining and viewing under UV illumination.

\section{Results}

\section{AIT bioassay}

Commercial products that are used in Mato Grosso do Sul were selected for use in this investigation and their use was based on the manufacturer's recommendations. Samples from 21 municipalities that represent all the microregions of Mato Grosso do Sul were tested in this study.

Only alpha-cypermethrin, cypermethrin and amitraz were commercially available as products with a single active ingredient, for use in the AIT evaluations. Table 1 shows that at the manufacturer's recommended application doses, the efficacy of the alphacypermethrin, cypermethrin and amitraz treatments was generally poor, on samples collected throughout the State. Table 2 shows the results from eight products that consisted of more than one active ingredient. The results indicated that acceptable tick control would be achieved on most farms across the State with three of the combination products. The AIT showed efficacy $\geq 90 \%$ from the use of DDVP + chlorfenvinphos (20 out of 21 farms), dichlorvos + cypermethrin (10 out of 16 farms) and cypermethrin + citronella + chlorpyrifos + piperonyl butoxide (20 out of 21 farms). Two mixtures showed $<90 \%$ efficacy in samples from every municipality: ethion + cypermethrin and DDVP + cypermethrin. The combinations of dichlorvos + chlorpyrifos, DDVP + deltamethrin and chlorpyrifos + cypermethrin showed mixed results depending on the specific city sample.

Ticks from the farm near Sonora were the most susceptible, since the efficacy was $\geq 90 \%$ from all the products tested, including those containing a single active ingredient. The Rio Negro sample was susceptible to 7 of the 11 active ingredient products tested. Conversely, the sample from Dourados was only susceptible to the combination of four active ingredients consisting of cypermethrin + citronella + chlorpyrifos + piperonyl butoxide. The Dourados region has a large number of dairy cattle operations, and the preferred breed in the Brazilian dairy production industry is based on Bos taurus and crossbred bovines, which require more intensive use of acaricides to control ticks.

\section{2. $k D r$-genotype frequency}

The presence of a sodium channel gene mutation in $R$. (B.) microplus from the municipalities of Paraiso, Rio Negro and Rochedo was assessed by testing 20 individual larvae from each sample. These samples were all pyrethroid resistant, as determined by the AIT assay. Only the wild-type pyrethroid-susceptible alleles were detected in our tests (data not shown). This assay only detects the single nucleotide difference that results in phenylalanine to isoleucine amino acid substitution in the S6 transmembrane segment of domain III. Although this mutation correlates with pyrethroid target-site resistance in Mexican ticks, its absence in these three samples from Mato Grosso do Sul does not preclude the presence of other sodium channel gene mutations or elevated metabolic enzyme activity that can cause pyrethroid resistance in R. (B.) microplus.

\section{Discussion}

The poor results from amitraz are of interest because this is one of the products most used in the State of Rio Grande do Sul, yet it only provided effective control in six of the 42 farms. However, in a previous report, amitraz in combination with chlorpyrifos was the most efficient product (CAMILLO et al., 2009). In surveys 
Table 1. Efficacy of acaricides in products containing a single active ingredient against $R$. (B.) microplus on farms in municipalities in the State of Mato Grosso do Sul.

\begin{tabular}{|c|c|c|c|}
\hline \multirow[t]{2}{*}{ Municipalities } & \multicolumn{3}{|c|}{ Active Ingredient* } \\
\hline & $\begin{array}{c}\text { Alpha- } \\
\text { cypermethrin }\end{array}$ & Cypermethrin & Amitraz \\
\hline Anastácio & 63 & 89 & 52 \\
\hline Bataguassu & 14 & 28 & 39 \\
\hline Caarapó & 36 & $-* *$ & - \\
\hline Chapadão do Sul & 54 & $70-75$ & $46-70$ \\
\hline Corguinho & 3 & 100 & 1 \\
\hline Dourados & 30 & 52 & 26 \\
\hline Iguatemi & 2 & 71 & 62 \\
\hline Inocência & - & - & 95 \\
\hline Itaquiraí & 11 & 85 & 0 \\
\hline Naviraí & 76 & 96 & 99 \\
\hline Nova Alvorada Sul & - & - & - \\
\hline Paraíso & 3 & - & - \\
\hline Paranaíba & 2 & 72 & 56 \\
\hline Ponta Porá & 66 & 88 & 75 \\
\hline Ribas do Rio Pardo & 29 & 51 & 61 \\
\hline Rio Negro & 47 & 100 & 100 \\
\hline Rochedo & 0 & - & 79 \\
\hline São Gabriel & 0 & 66 & 0 \\
\hline Sidrolândia & $3-60$ & - & $32-96$ \\
\hline Sonora & 100 & 100 & - \\
\hline Terenos & 10 & - & 84 \\
\hline
\end{tabular}

*Products containing one acaricide were tested at the application doses recommended by the manufacturer: alpha-cypermethrin $(0.015 \%)$, cypermethrin $(0.015 \%)$ and amitraz $(0.025 \%)$. Efficacy is reported as the proportion (\%) of the estimated reproduction (ER) of the adult females in a treatment group. ${ }^{* *}$ Not tested.

in other Brazilian States, amitraz alone also performed poorly (CAMPOS JÚNIOR et al., 2005; PEREIRA, 2006).

The ineffectiveness of alpha-cypermethrin and cypermethrin as single active-ingredient products in Mato Grosso do Sul was clear. This reflects patterns seen in earlier resistance surveys. In Rio Grande do Sul, cypermethrin alone was effective in only 65\% of the tests (CAMILLO et al., 2009) and in the State of Bahia, deltamethrin was effective in only $65 \%$ of the tests (CAMPOS JÚNIOR et al., 2005). Fernandes (2001) reported that in the State of Goiás, ticks were resistant to commercial concentrations of deltamethrin and cypermethrin. Pereira (2006) reported that the efficiency of permethrin in the State of São Paulo was only 28\%, and Mendes et al. (2007) reported resistance to cypermethrin at levels of 75 and $41.7 \%$. Finally, Silva et al. (2005) reported that the resistance to cypermethrin in Paraiba was $70.5 \%$.

The Brazilian Santa Luiza strain of the southern cattle tick (R. (B.) microplus) is also resistant to permethrin. Studies by Li et al. (2008) suggested that permethrin resistance was inherited as an incomplete recessive trait and that one major gene was responsible for permethrin resistance. Additionally, selection of F3 larvae with either permethrin or amitraz led to significantly increased resistance to both permethrin and amitraz, thus indicating a close linkage between the genes responsible for permethrin and amitraz resistance.
These results demonstrate that most drugs used for controlling $R$. (B.) microplus in Mato Grosso do Sul had low efficacy on adult ticks, as measured by in vitro tests, with similar results reported in other States. Clearly, selection for resistance to acaricides has occurred throughout the State. However, from the research presented here, it is not known whether the resistance levels detected among adult ticks in vitro amount to actual field control failure at the larval, nymph and partially engorged adult stages of these ticks. Adequate control may still be possible with these products, even with indications of resistance among engorged adult females, if the concentrations used are sufficient to kill other life stages that are present in the host animal, which may be more susceptible to this same concentration of acaricide (DAVEY et al. 2004).

For field efficacy measurements, there is no substitute for on-animal efficacy studies using a formulated acaricide with a known commercial concentration, strictly following the label recommendations. It is likely that acaricides that are effective on adult females would also be effective on earlier life stages. However, further research using the abovementioned techniques needs to be conducted on suspected resistant populations in order to confirm the resistance and study the mechanistic basis of this resistance, before strong conclusions can be drawn regarding the state of acaricide resistance in this area of Brazil. Another possibility to consider when addressing questions of acaricide resistance and suspected product failure is product quality. We did not chemically analyze the products used in our study, and active ingredient degradation could not conclusively be ruled out as a factor in the AIT results.

Currently, the level of resistance in a tick population is determined by means of bioassay techniques. The bioassay procedures are valuable for their portability and low cost. However, these tests do not reveal direct information about the genetics of the samples and cannot detect resistance in its early stages of development with much precision. It often takes several weeks to obtain results. An assay that could determine the resistance status of individual Brazilian ticks within a day would be helpful: hence our interest in the rapid diagnostic capability of the sodium channel PCR assay.

Susceptibility to synthetic pyrethroids was evaluated in Mexican $R$. (B.) microplus tick populations (ROSARIO-CRUZ et al., 2009). Knockdown resistance (kdr) PCR allele-specific assays were conducted in tick populations that were resistant to cypermethrin, flumethrin and deltamethrin. A significant correlation $(\mathrm{p}<0.01)$ was found between presence of the sodium channel mutation, and resistance to synthetic pyrethroids as measured by means of PCR and the larval packet test (LPT) respectively. Just over half the populations $(16 / 28)$ were cross-resistant to flumethrin, deltamethrin and cypermethrin, $21.4 \%$ of the samples $(6 / 28)$ were susceptible to all of the three pyrethroids, $10.7 \%(3 / 28)$ were resistant to flumethrin, 3.4\% (1/28) were resistant to deltamethrin only and $7.1 \%(2 / 28)$ were resistant to both flumethrin and deltamethrin. The presence of the $k d r$ mutation correlated with resistance to synthetic pyrethroids as a class. Target-site insensitivity was the major mechanism of resistance to synthetic pyrethroids in Mexican $R$. (B.) microplus field strains, involving the presence of a sodium channel mutation. However, esterase-based mechanisms, 
Table 2. Efficacy of acaricides in combination products against $R$. (B.) microplus on farms in municipalities in the State of Mato Grosso do Sul.

\begin{tabular}{|c|c|c|c|c|c|c|c|c|}
\hline \multirow[t]{3}{*}{ Municipalities } & \multicolumn{8}{|c|}{ Acaricide combinations* } \\
\hline & DLV & CPF & DDVP & DDVP & ETH & CPT, CPF & DLV & DDVP \\
\hline & CPT & CPT & DMT & CFF & CPT & CTR, PBO & CPF & CPT \\
\hline Anastácio & 96 & 95 & 25 & 100 & 77 & 100 & 100 & 54 \\
\hline Bataguassu & 86 & 93 & 14 & 99 & - & 97 & 90 & - \\
\hline Caarapó & -** & 48 & - & 100 & - & 100 & - & - \\
\hline Chapadão do Sul & $91-99$ & 94 & $4-58$ & 100 & $64-89$ & $82-100$ & $43-94$ & $50-80$ \\
\hline Corguinho & - & - & - & 100 & - & 100 & 39 & - \\
\hline Dourados & 83 & 54 & 22 & 34 & 34 & 98 & 67 & 16 \\
\hline Iguatemi & 100 & 0 & 88 & 100 & 20 & 100 & 71 & 19 \\
\hline Inocência & - & - & 99 & 100 & - & 100 & 99 & - \\
\hline Itaquiraí & 100 & 94 & 13 & 100 & 62 & 100 & 100 & 15 \\
\hline Naviraí & 97 & 100 & 83 & 100 & 89 & 100 & 100 & 60 \\
\hline Nova Alvorada Sul & - & - & - & 90 & 12 & 100 & 12 & - \\
\hline Paraíso & - & - & - & 100 & 28 & 100 & - & - \\
\hline Paranaíba & 51 & 3 & 22 & 100 & 3 & 100 & 45 & 41 \\
\hline Ponta Porá & 100 & - & - & 100 & 88 & 100 & 100 & 75 \\
\hline Ribas Rio Pardo & 100 & - & 12 & 100 & - & 100 & 100 & 66 \\
\hline Rio Negro & 100 & 73 & 100 & 100 & 44 & 100 & 100 & 77 \\
\hline Rochedo & 63 & 78 & 0 & 100 & - & 100 & - & - \\
\hline São Gabriel & 88 & 0 & 43 & 100 & 24 & 100 & 56 & 16 \\
\hline Sidrolândia & 100 & 80 & 100 & 100 & 28 & 100 & $40-99$ & - \\
\hline Sonora & 100 & - & 100 & 100 & - & 100 & 100 & - \\
\hline Terenos & 46 & - & - & 100 & - & 100 & - & - \\
\hline
\end{tabular}

Abbreviations: DLV: dichlorvos; CPT: cypermethrin; CPF: chlorpyrifos; CFF: chlorfenvinphos; DMT: deltamethrin; CTR: citronella; PBO: piperonyl butoxide; DDVP: DDVP; ETH: ethion. *Combination products were tested at the application dose recommended by the manufacturer: dichlorvos $(0.1125 \%)+$ cypermethrin $(0.0125 \%)$; chlorpyrifos $(0.04 \%)+$ cypermethrin $(0.0165)$; DDVP $(0.15 \%)+$ deltamethrin $(0.0025 \%)$; DDVP $(0.15 \%)+$ chlorfenvinphos $(0.05 \%)$; ethion $(0.06 \%)+$ cypermethrin $(0.008 \%)$; cypermethrin $(0.015 \%)+$ citronella $(0.001 \%)+$ chlorpyrifos $(0.025 \%)+$ piperonyl butoxide $(0.015 \%)$; dichlorvos $(0.15 \%)$ + chlorpyrifos $(0.05 \%)$; DDVP $(0.15 \%)+$ cypermethrin $(0.1125 \%)$. Efficacy is reported as the proportion (\%) of the estimated reproduction (ER) of the adult females in a treatment group. ${ }^{* *}$ Not tested.

other mutations or combinations of mechanisms can also occur (JAMROZ et al., 2000; ROSARIO-CRUZ et al., 2009).

We did not detect the presence of this mutation in the three suspected pyrethroid-resistant samples tested in this study. We also tested seven other samples from other locations in the state and did not find the sodium channel gene mutation (data not shown). Potentially, there is a different resistance mechanism involved, such as esterase detoxification, as detected in Mexican ticks by Jamroz et al. (2000). Alternatively, there may be a different sodium channel gene mutation in these ticks. Jonsson et al. (2010) recently reported on a new sodium channel gene mutation that confers pyrethroid resistance in Australian ticks.

Our results provide further evidence supporting the notion that resistance to the products available in Brazil is developing. There is concern regarding the future availability of efficient products for tick control. Emergence of resistance is a constant challenge and resistance is always a major driver of new antiparasitic drug development.

\section{Acknowledgements}

Thank are due to Embrapa, CNPq and Fundect-MS for financial support; to Dr. João Ricardo Martins for providing the Mozo strain; and to Jason P. Tidwell for technical assistance with larval PCRs.

\section{References}

ANDREOTTI, R. Situação atual da resistência do carrapato-do-boi Rhipicephalus (Boophilus) microplus aos acaricidas no Brasil. Campo Grande: Embrapa Gado de Corte, 2010.36 p. (Documentos / Embrapa Gado de Corte, 180). Disponível em: <http://www.cnpgc.embrapa.br/ publicacoes/doc/DOC180.pdf>. Acesso em: 30 dez. 2010.

ANUÁRIO da Pecuária Brasileira - ANUALPEC. São Paulo: Agra FNP Pesquisas Ltda, 2009.

ARANTES, G. J.; MARQUES, A. O.; HONER, M. R. O carrapato do bovino, Boophilus microplus, no município de Uberlândia, MG: análise da sua resistência contra carrapaticidas comerciais. Revista Brasileira de Parasitologia Veteterinária, v. 4, n. 2, p. 89-93, 1995.

BARROS, A. T. M.; GOMES, A.; KOLLER, W. W. Insecticide susceptibility of horn flies, Haematobia irritans (Diptera: Muscidae), in the State of Mato Grosso do Sul, Brazil. Revista Brasileira de Parasitolgia Veterinária, v. 16, n. 3, 145-151, 2007. PMid:18078601.

CAMILLO, G. et al. Eficiência in vitro de acaricidas sobre carrapatos de bovinos no Estado do Rio Grande do Sul, Brasil. Ciência Rural, v. 39, n. 2, p. 490-495, 2009. http://dx.doi.org/10.1590/S010384782008005000082

CAMPOS JÚNIOR, D. A.; OLIVEIRA, P. R. Avaliação in vitro da eficácia de acaricidas sobre Boophilus microplus (Canestrini, 1887) (Acari: Ixodidae) de bovinos no município de Ilhéus, Bahia, Brasil. Ciência Rural, v. 35, n. 6, p. 1386-1392, 2005. 
DAVEY, R. B.; GEORGE, J. E.; MILLER, R. J. Control of an Organophosphate-Resistant Strain of Boophilus microplus (Acari: Ixodidae) Infested on Cattle After a Series of Dips in Coumaphos Applied at Different Treatment Intervals. Journal of Medical Entomology, v. 41, n. 3, p. 524-528, 2004. PMid:15185959. http://dx.doi. org/10.1603/0022-2585-41.3.524

DRUMMOND, R. O. et al. Boophilus annulatus and B. microplus: Laboratory tests of insecticides. Journal of Economic Entomology, v. 66, n. 1, p.130-133, 1973. PMid:4690254

FERNANDES, F. F. Toxicological effects and resistance to pyrethroids in Boophilus microplus from Goiás, Brazil. Arquivo Brasileiro de Medicina Veterinária e Zootecnia, v. 53, n. 5, p. 538-543, 2001. http://dx.doi. org/10.1590/S0102-09352001000500004

FREIRE, J. J. Arseno e cloro resistência e emprego de tiofosfato de dietilparanitrofenila (Parathion) na luta anticarrapato Boophilus microplus (Canestrini, 1887). Boletim da Diretoria de Produçáo Animal, v. 9, n.17, p. 3-21, 1953.

GRISI, L. et al. Impacto econômico das principais ectoparasitoses em bovinos no Brasil. A Hora Veterinária, v. 21, n. 125, p. 8-10, 2002.

GUERRERO, F. D.; DAVEY, R. B.; MILLER, R. J. Use of an AlleleSpecific Polymerase Chain Reaction Assay to Genotype Pyrethroid Resistant Strains of Boophilus microplus (Acari: Ixodidae). Journal of Medical Entomology, v. 38, n. 1, p. 44-50, 2001. PMid:11268690. http://dx.doi.org/10.1603/0022-2585-38.1.44

JAMROZ, R. C. et al. Molecular and biochemical survey of acaricide resistance mechanisms in larvae from Mexican strains of the southern cattle tick, Boophilus microplus. Journal of Insect Physiology, v. 46, n. 5 , p. 685-695, 2000. http://dx.doi.org/10.1016/S0022-1910(99)00157-2

JONSSON, N. N. et al. Identification of a mutation in the para-sodium channel gene of the cattle tick Rhipicephalus microplus associated with resistance to flumethrin but not to cypermethrin. International Journal of Parasitology, v. 40, n. 14, p. 1659-1664, 2010. PMid:20708620. http://dx.doi.org/10.1016/j.ijpara.2010.07.006

KLAFKE, G. M. et al. Larval Immersion Tests with ivermectin in populations of the cattle tick Rhipicephalus (Boophilus) microplus (Acari: Ixodidae) from State of Sao Paulo, Brazil. Veterinary Parasitology, v. 142, n. 3-4,p. 386-390, 2006. PMid:16904265. http://dx.doi.org/10.1016/j. vetpar.2006.07.001
KOLLER, W. W.; GOMES, A.; BARROS, A. T. M. Diagnóstico da resistência do carrapato-do-boi a carrapaticidas em Mato Grosso do Sul. Campo Grande: Embrapa Gado de Corte, 2009. 47 p. (Boletim de Pesquisa e Desenvolvimento).

LI, A. Y. et al. Genetics and mechanisms of permethrin resistance in the Santa Luiza strain of Boophilus microplus (Acari: Ixodidae). Journal of Medical Entomology, v. 45, n. 3, p. 427 - 438, 2008. http://dx.doi. org/10.1603/0022-2585(2008)45[427:GAMOPR]2.0.CO;2

MARTINS, J. R.; FURLONG, J. Avermectin resistance of the cattle tick Boophilus microplus in Brazil. Veterinary Record, v. 149, n. 2, p. 64, 2001.

MENDES, M. C.; PEREIRA, J. R.; PRADO, A. P. Sensitivity of Boophilus microplus (Acari: Ixodidae) to pyrethroids and organophosphate in farms in the Vale do Paraíba region, São Paulo, Brazil. Arquivos do Instituto Biológico, v. 74, n. 2, p. 81-85, 2007.

MILLER, R. J.; DAVEY, R. B.; GEORGE, J. E. First report of organophosphate-resistant Boophilus microplus (Acari: Ixodidae) within the United States. Journal of Medical Entomology, v. 42, n. 5, p. 912-917, 2005. http://dx.doi.org/10.1603/0022-2585(2005)042[0912:FROOB $\mathrm{M}] 2.0 . \mathrm{CO} ; 2$

PEREIRA, J. R. Eficácia in vitro de formulações comerciais de carrapaticidas em teleóginas de Boophilus microplus coletadas de bovinos leiteiros do Vale do Paraíba, Estado de São Paulo. Revista Brasileira de Parasitologia Veterinária, v. 15, n. 2, p. 45-48, 2006.

ROSARIO-CRUZ, R. et al. Roles played by esterase activity and by a sodium channel mutation involved in pyrethroid resistance in populations of Boophilus microplus (Acari: Ixodidae) collected from Yucatán, Mexico. Journal of Medical Entomology, v. 42, n. 6, p. 1020-1025, 2005. PMid:19565267. PMCid:2729983. http://dx.doi.org/10.1007/s00436009-1539-1

ROSARIO-CRUZ, R. et al. Molecular survey of pyrethroid resistance mechanisms in Mexican field populations of Rhipicephalus (Boophilus) microplus. Parasitology Research, v. 105, n. 4, p. 1145-1153, 2009.

SILVA, W. W. et al. Resistência de fêmeas ingurgitadas de Boophilus microplus e Rhipicephalus sanguineus (Acari: Ixodidae) a carrapaticidas no semi-árido paraibano: efeito da cipermetrina e do amitraz. Agropecuária Científica no Semi-árido, v. 1, p. 59-62, 2005. 